\title{
Epstein-Barr Virus Reactivation Associated with Diminished Cell-Mediated Immunity in
}

Antarctic Expeditioners

Satish K. Mehta, Ph.D.; Duane L. Pierson, Ph.D.; Helen Cooley, M.B., B.S.; Robin Dubow, M.B., B.S.; and Desmond Lugg, M.D.

NASA-Johnson Space Center (D.P.), Houston; Enterprise Advisory Services Inc. (S.M.), Houston, Texas, USA; Australian Antarctic Division (H.C., R.D., D.L.), Hobart, Tasmania, Australia

Work was performed at the NASA-Johnson Space Center, Houston, Texas, USA

CORRESPONDING AUTHOR: D. L. Pierson, Ph.D., Life Sciences Research Laboratories, Mail Code SD3, NASA-Johnson Space Center, Houston, TX 77058; Tel 281-483-7166; fax 281-483-3058; e-mail dpierson@ems.jsc.nasa.gov

Running head: Virus shedding in Antarctic expeditioners

To be submitted to Journal of Medical Virology. 


\begin{abstract}
Reactivation of Epstein-Barr virus (EBV) and cell-mediated immune (CMI) responses were
\end{abstract} followed in 16 Antarctic expeditioners during winter-over isolation at two Australian National Antarctic Research Expedition stations. Delayed-type hypersensitivity skin testing was used as an indicator of the CMI response, which was evaluated two times before winter isolation and three times during isolation. At all five evaluation times, 8 or more of the 16 subjects had a diminished CMI response. Diminished CMI was observed on every test occasion in 4/16 subjects; only $2 / 16$ subjects exhibited normal CMI responses for all five tests. A polymerase chain reaction (PCR) assay was used to detect EBV DNA in saliva specimens collected before, after, and during the winter isolation. EBV DNA was present in $17 \%$ (111/642) of the saliva specimens; all 16 subjects shed EBV in their saliva on at least one occasion. The probability of EBV shedding increased ( $\mathrm{p}=0.013$ ) from $6 \%$ before or after winter isolation to $13 \%$ during the winter period. EBV appeared in saliva during the winter isolation more frequently ( $<<0.0005$ ) when CMI responsiveness was diminished than when CMI status was normal. The findings indicate that the psychosocial, physical, and other stresses associated with working and living in physical isolation during the Antarctic winter results in diminished CMI and an accompanying increased reactivation and shedding of latent viruses.

Key words: Antarctica, Epstein-Barr virus, cell-mediated immunity 


\section{INTRODUCTION}

Epstein-Barr virus (EBV) is one of eight currently recognized human herpesviruses and is capable of establishing a life-long infection of its human host. It infects an estimated 90 to $95 \%$ of the adult population worldwide and is the causative agent of infectious mononucleosis, Burkitt's lymphoma, nasopharyngeal carcinoma, and other rare lymphomas [Oxman, 1986; Rand et al., 1990; Lennette, 1991]. The establishment of viral latency and subsequent reactivation are not well understood, but factors such as emotional stress, trauma, sunlight, respiratory infections, fever, and specific changes in the immune response are known to increase the incidence and duration of reactivation and shedding of some latent viruses [Kasl et al., 1979; Glaser et al., 1985; Gosselin et al., 1992; Glaser et al., 1995].

Latent viruses pose an important infectious disease risk to astronauts' health during space flight, and this risk almost certainly increases as the duration of space missions increases. Restricting preflight contact of the flight crews with high-risk populations reduces risks associated with many infectious agents. However, risks associated with latent viruses remain unabated by such precautions.

The immune system, specifically the cell-mediated immunity (CMI) component, typically limits EBV infections after reactivation and prevents further systemic disease [Tosato et al., 1984]. Decreased CMI response may lead to viral reactivation, resulting in asymptomatic viral shedding, localized infections, or disseminated infections. Previous studies demonstrated decreased CMI response during space flight [Taylor and Janney, 1992 ; Taylor, 1993].

The Australian National Antarctic Research Expeditions (ANARE) operates research stations on the Antarctic continent and on a sub-Antarctic island station year-round, and many science investigations have been conducted during their 50-year presence [Lugg, 1994]. These stations are among the most isolated on Earth and expose expeditioners to different types and levels of stress. Living on one of these stations is similar in many ways to living in space, and recently the Antarctic has 
been identified as a valuable ground-based analog to simulate some aspects of space flight [Ember, 1998]. The CMI response has been studied extensively at the Antarctic stations and been found to decrease during the winter-over isolation period [Williams et al., 1986; Muller et al., 1988; Muller et al., 1995a; Muller et al., 1995b]. This study was undertaken to assess concurrently the CMI response and the reactivation and shedding of EBV during the 8-month total physical isolation of an Antarctic winterover expedition. 


\section{MATERIALS AND METHODS}

\section{Subjects}

Sixteen subjects ( 14 males and 2 females), aged 26 to 56 years participated in this study at two Antarctic stations. Ten of these subjects were from the Davis station and 6 from the Mawson station. Both stations are inside the Antarctic Circle. All human study protocols were approved by the Ethics Committee of the Australian Antarctic Division and the Institutional Review Board of the Johnson Space Center.

\section{Saliva samples}

Saliva samples were collected upon arising between once and three times a week before, during, and after the isolation. A total of 642 saliva samples were collected, 359 from 10 subjects at Davis Station and 283 from 6 subjects at Mawson Station. Samples were stored at $-70^{\circ} \mathrm{C}$ until the completion of the winter-over period, when they were placed in liquid nitrogen and returned by ship to the Australian Antarctic Division in Hobart, Tasmania, Australia. Subsequently, specimens were flown on dry ice to the Johnson Space Center in Houston for analysis.

\section{Sample processing}

Saliva specimens were concentrated by spinning at $8000 \mathrm{rpm}(6726 \mathrm{xg})$ for 2 hours in a $100 \mathrm{KD}$ filtration unit (Filtron Technology Corp., Northborough, MA) and extracted by a nonorganic extraction method (Qiagen Inc., Chatsworth, CA). Microcarrier gel ( $2 \mu \mathrm{l} / \mathrm{ml}$ ) (Molecular Research Center Inc., .

Cincinnati, $\mathrm{OH}$ ) was added to facilitate DNA recovery at the proteinase $\mathrm{K}$ digestion step (Boehringer Mannheim, Indianapolis, IN). DNA was resuspended in $50 \mu \mathrm{l}$ of water (sterile nuclease-free biotechnology grade) (Amresco, Solon, OH). EBV DNA for control studies was obtained from Sigma 
Chemical Co. (St. Louis, MO). The following polymerase chain reaction (PCR) primers directed at the EBV polymerase accessory protein gene (BMRF1) were used: P1, 5'-3' GTC CAA GAG CCA CCA CAC CTG (The Midland Certified Reagent Co., Midland, TX) and P2, 5-3' Biotin CCC AGA AGT ATA CGT GGT GAC GTAGA (Digene Diagnostics, Gaithersburg, MD). These primers were used at a concentration of $200 \mu \mathrm{M}$ with $10 \mu \mathrm{M}$ deoxyribonucleic acid triphosphates (Perkin-Elmer, Branchburg, NJ). PCR was optimized with buffer II (Perkin-Elmer, Foster City, CA) with $2.5 \mathrm{mM} \mathrm{MgCl}_{2}$, using Perkin-Elmer

GenAmp system 9600. DMSO (Sigma, St. Louis, MO) was added to a final concentration of 5\%. AmpliGold (Perkin-Elmer, Foster City, CA) (2.5 units per $100 \mu 1$ reaction mixture) was added, and $5 \mu \mathrm{I}$ of the purified DNA was added to $20 \mu \mathrm{l}$ of the reaction mixture. The cycle parameters were $95^{\circ} \mathrm{C}$ for $9 \mathrm{~min}$, followed by 40 cycles of $94^{\circ} \mathrm{C}$ for $15 \mathrm{~s}, 61^{\circ} \mathrm{C}$ for $15 \mathrm{~s}$, and $72^{\circ} \mathrm{C}$ for $15 \mathrm{~s}$, with a final extension step at $72^{\circ} \mathrm{C}$ for 5 min. PCR fragments were detected with the PCR Sharp System (Digene Diagnostics, Gaithersburg, MD) after $24 \mathrm{~h}$ [Payne et al., in press].

\section{Cell-mediated immunity assessment}

The CMI status of each subject was assessed 5 times during the year in Antarctica, including the winter isolation period. The CMI Multitest (Institut Mérieux, Lyon, France), with a disposable standardized intradermal antigen applicator, was loaded with 7 antigens and a glycerine control [Kniker et al., 1979; Muller et al., 1995a; Muller et al., 1995b]. The antigens in this test were tetanus, diphtheria, Streptococcus, tuberculin, Candida albicans, Trichophyton, and Proteus. Reactions were recorded after 48 $\mathrm{h}$ as the area of induration measured in millimeters with calipers; reactions were considered positive if the diameter of induration was $\geq 2 \mathrm{~mm}$. Subject score was recorded as the total millimeters of induration from all 7 test antigens. The following criteria were used to assess CMI multitest results [Williams et al., 1986; Muller et al., 1995a]: subjects with one or less positive antigen reaction, with a subject score of less than 5 
$\mathrm{mm}$, were designated anergic; subjects with subject scores of less than $10 \mathrm{~mm}$ were hypoergic; and subjects with subject scores of more than $10 \mathrm{~mm}$ were designated normal responders. All CMI testing was conducted by station physicians trained in the procedures.

\section{Statistical Analysis}

A multilevel statistical model [Goldstein, 1995] with a binomial response variable was used to compare the incidence of viral shedding during the isolation and nonisolation periods. This model assumes random differences between subjects' probability of shedding are normally distributed on a logistic scale. To study the effect of CMI status on the propensity for EBV shedding, we did not assume normally distributed errors at the subject level, but instead used the method of generalized estimating equations (GEE) [Zeger et al., 1988; McCullagh and Nelder, 1989]. The less presumptive GEE model was used because only five measurements of CMI status were obtained per subject. Both methods take into account the repeated observations on subjects throughout the study period. 


\section{RESULTS}

Sixteen subjects from two stations were studied during an Antarctic expedition to determine their EBV DNA shedding patterns and CMI status. The CMI status was measured on five different occasions: two before the winter isolation and three during the isolation period. Table I shows that 8 to 11 of the 16 subjects at any one test time exhibited diminished (either hypoergy or anergy) CMI responses. Only 2 of 16 subjects had a normal CMI response at all test times; 4 subjects had diminished CMI at all test times.

All 16 subjects shed EBV DNA during the expedition. EBV DNA was detected in 17\% (111/642) of the samples collected from subjects before, after, and during the winter isolation period. As expected, the shedding frequency varied considerably among individuals. However, the shedding frequencies observed at the two stations were not significantly different $(p=0.168)$. Salivary shedding frequencies varied from 2 to $39 \%$ among the expeditioners. Shedding patterns of two subjects with the highest shedding frequencies (39\% and 38\%) are shown in Figure 1. The CMI responses of all four subjects were diminished (hypoergic or anergic) at one or more test times during the winter isolation. Of the $20 \mathrm{CMI}$ tests conducted on these four subjects during the study, 16 resulted in anergic or hypoergic reactions.

The presence of EBV DNA was significantly greater in saliva samples collected during winter isolation than before the isolation period. Using a multilevel logistic model, the probability of EBV shedding was found to significantly increase $(\mathrm{p}=0.013)$ from $6 \%$ before or after winter isolation to $13 \%$ during the winter period (Figure 2).

Using a generalized linear model to account for random differences between subjects, we examined EBV DNA data during periods of diminished CMI (Figure 3). During winter isolation, EBV DNA was shed more frequently when CMI was diminished (24\%, 86/358 samples) than when CMI 
responses were normal $(6 \%, 13 / 207)$. However, before and after the winter isolation, observed increases in EBV DNA shedding did not correlate with diminished CMI. 


\section{DISCUSSION}

This is the first report on salivary shedding of EBV (EBV DNA) in Antarctic expeditioners. Likewise, this is the first study correlating of frequency of EBV in saliva with diminished CMI. The Australian Antarctic Division maintains three research stations in Antarctica and one on the subAntarctic island of Macquarie. Investigators in the Division have previously shown immune changes in subjects at the Antarctic stations, including diminished CMI responses during the winter isolation [Williams et al., 1986; Muller et al., 1988; Schmitt and Schaffar, 1993; Muller et al., 1995a; Muller et al., 1995b; Tingate et al., 1997]. Our observation of diminished CMI responses in over 50\% of the subjects during winter isolation agrees with previous findings. Muller et al. [1995a] reported 36\% hypoergy in subjects in the Antarctic. Lugg (unpublished results) has reported up to $60 \%$ diminished CMI in wintering groups of Antarctic expeditioners. Unfortunately, baseline (before or after going to Antarctica) measurements of CMI responses were not conducted in our study due to the subjects' unavailability during the desired baseline periods. However, all expeditioners selected for the winter isolation undergo a rigorous medical examination to ensure a healthy population for the 9 to 10 months of total physical isolation during the Antarctic winter. No physical contact with outside populations occurs during the winter isolation because of the harsh, remote environment. Muller et al. [1995b] showed that the diminished CMI responses observed during a 56-day expedition to Antarctica returned to normal after the subjects returned to Australia. Taylor [1993] reported similar CMI reductions in astronauts during short space flights; Konstantinova et al. [1993] found reductions in CMI responses during long space flights.

EBV DNA shedding was found in saliva of astronauts participating in four 9 to 14-day flights aboard the space shuttle [Payne et al., in press]. CMI was not measured on these missions. However, EBV DNA shedding was monitored during 60- and 90-day closed-chamber studies and was found to 
occur more frequently during the in-chamber phase than before or after that phase [Mehta et al., 1998]. CMI status was determined during the 90-day chamber study and was found to be diminished (C. Sams, personal communication) similarly as reported in the Antarctic studies and during space flight.

In the current study, the observed diminished CMI response and increased EBV DNA shedding in saliva may be the result of stress during the winter isolation. Wood et al. [1999] have described various types of stress experienced during the Antarctic winter, and Glaser et al. [1995] have described the effects of various stressors on EBV reactivation. Meehan et al. [1992] described the effects of psychoneuroendocrine factors during space flight. Many of these effects are mediated through the hypothalamus-pituitary-adrenal axis. Future studies integrating stress evaluations and measurements of stress hormones, immune functions, and latent virus reactivation are scheduled for an upcoming Antarctic expedition. 


\section{ACKNOWLEDGMENTS}

This work was supported by National Aeronautics and Space Administration funding (111-30-10-03; 111-30-10-06) and the Australian Antarctic Division. The authors express their appreciation to the members of the Australian National Antarctic Research Expedition for their cooperation, which was essential to these studies. We also thank Dr. Jane Krauhs of Wyle Laboratories for editorial assistance, Dr. Alan Feiveson of the Johnson Space Center for statistical analysis of the data, and Dennis Quinn of the University of Tasmania for training the physicians in the use of CMI Multitest. 


\section{REFERENCES}

Ember LR. 1998. Surviving stress. Chemical \& Engineering News 76(21):16-17.

Glaser R, Kurt LA, MacCallum RC, Malarkey WB. 1995. Hormonal modulation of Epstein-Barr virus replication. Neuroendocrinology 62:356-361.

Glaser R, Kiecolt-Glaser JK, Speicher CE, Holliday JE. 1985. Stress, loneliness, and changes in herpesvirus latency. J Behav Med 8:249-260.

Goldstein H. 1995. Multilevel statistical models. London: Edward Arnold. p 106-108.

Gosselin J, Flamand L, D'Addario M, Hiscott J, Stefanescu I, Ablashi DV, Gallo RC, Menezes J. 1992.

Modulatory effects of Epstein-Barr, herpes simplex, and human herpes-6 viral infections and coinfections on cytokine synthesis. A comparative study. J Immunol 149:181-187.

Kasl SV, Evan AS, Niederman JC. 1979. Psychosocial risk factors in the development of infectious mononucleosis. Psychosom Med 41:445-466.

Konstantinova IV, Rykova MP, Lesnyak AT, Antropova EA. 1993. Immune changes during longduration missions. J Leukoc Biol 54:189-201.

Kniker WT, Anderson CT, Roumiantzeff M. 1979. The multi-test system: a standardized approach to evaluation of delayed hypersensitivity and cell-mediated immunity. Ann Allergy 43:73-79.

Lennette ET. 1991. Epstein-Barr virus. In: Balows A, Hausler WJ, Herrmann KL, Isenberg HD, Shadomy HJ, editors. Manual of clinical microbiology. Washington, DC: American Society for Microbiology, p 847-852. 
Lugg DJ. 1994. Antarctica as a space laboratory. In: Hempel G, editor. Antarctic science: global concerns. Berlin: Springer-Verlag, p 229-242.

McCullagh P, Nelder JA. 1989. Generalized linear models. 2nd ed. London: Chapman \& Hall.

Meehan RT, Neale LS, Kraus ET, Stuart CA, Smith ML, Cintron NM., Sams CF. 1992. Alteration in human mononuclear leucocytes following space flight. Immunology 76:491-497.

Mehta SK, Lugg DJ, Payne DA, Tyring SK, Pierson DL. 1998. Epstein-Barr virus reactivation in spacecraft and ground based space analogs. Gravitational and Space Biology Bulletin 12:81.

Muller HK, Lugg DJ, Quinn D. 1995a. Cell mediated immunity in Antarctic wintering personnel; 19841992. Immunol Cell Biol 73:316-320.

Muller HK, Lugg DJ, Ursin H, Quinn D, Donovan K. 1995b. Immune responses during an Antarctic summer. Pathology 27:186-190.

Muller HK, Lugg DJ, Williams DL. 1988.Cutaneous immune responses in Antarctica. A reflection of immune status? Arctic Med Res 47:249-251.

Oxman MN. 1986. Herpes stomatitis. In: Braude A, Davis C, Fierer J, editors. Infectious diseases and medical microbiology. Philadelphia: W.B. Saunders Company, p 752-769.

Payne D, Mehta SK, Tyring SK, Stowe RS, Pierson DL. 1999. Incidence of Epstein-Barr virus in astronaut saliva during spaceflight. Aviat Space Environ Med. In press.

Rand KH, Hoon EF, Massey JK, Johnson JH. 1990. Daily stress and recurrence of genital herpes simplex. Arch Intern Med 150:1889-1893.

Schmitt DA, Schaffar L. 1993. Confinement and immune function. Adv Space Biol Med 3:229-235. 
Tosato G, Steinberg AD, Yarchoan R, Heilman CA, Pike SE, De Seau V, Blaese RM. 1984. Abnormally elevated frequency of Epstein-Barr virus-infected B cells in the blood of patients with rheumatoid arthrit is. J Clin Invest 73:1789-1795.

Tingate TR, Lugg DJ, Muller HK, Stowe RP, Pierson DL. 1997. Antarctic isolation: immune and viral studies. Immunol Cell Biol 75:275-283.

Taylor GR, Janney RP. 1992. In vivo testing confirms a blunting of the human cell-mediated immune mechanism during space flight. J Leukoc Biol 51:129-132.

Taylor GR. 1993. Immune changes during short-duration missions. J Leukoc Biol 54:202-208.

Williams DL, Climie A, Muller HK, Lugg DJ. 1986. Cell-mediated immunity in healthy adults in Antarctica and the sub-Antarctic. J Clin Lab Immunol 20:43-49.

Wood JA, Lugg D, Hysong SJ, Harm DL. 1999. Is it so really bad? A comparison of positive and negative experiences in Antarctic winter stations. Environment and Behavior. In press.

Zeger SL, Liang K-Y, Albert PS. 1988. Models for longitudinal data: a generalized estimating equation approach. Biometrics 44:1049-1060. 


\section{FIGURE LEGENDS}

Figure 1. Two subjects' viral shedding patterns-as shown by the optical density of Epstein-Barr virus DNA at $405 \mathrm{~nm}$ (EBV DNA OD @ $405 \mathrm{~nm}$ )—and cellmediated immunity (CMI) status before (Pre) and during winter isolation.

Figure 2. EBV shedding probability before and after isolation (A) and during winter isolation (B) in Antarctica.

Figure 3. EBV shedding and CMI response during isolation. Circles represent best estimates of $\mathrm{P}(\mathrm{EBV})=$ probability of EBV shedding with the indicated CMI response. Upper and lower $90 \%$ confidence limits are indicated by squares and triangles respectively. 
Table I. CMI multitest responses of 16 subjects during the preisolation and isolation (8month Antarctic winter-over) periods

\section{CMI response}

\begin{tabular}{|c|c|c|c|c|c|}
\hline & \multicolumn{2}{|c|}{ Preisolation } & \multicolumn{3}{|c|}{ Isolation } \\
\hline & Test 1 & Test 2 & Test 3 & Test 4 & Test 5 \\
\hline 1 & $\mathrm{~N}$ & $\mathrm{~A}$ & $\mathrm{H}$ & $\mathrm{H}$ & $\mathrm{N}$ \\
\hline 2 & A & $N$ & $\mathrm{H}$ & $\mathrm{N}$ & $\mathrm{H}$ \\
\hline 3 & $\mathrm{~N}$ & A & $N$ & $\mathrm{H}$ & $\mathrm{H}$ \\
\hline 4 & $A$ & A & $\mathrm{A}$ & A & A \\
\hline 5 & $\mathrm{~N}$ & $\mathrm{H}$ & $\mathrm{N}$ & A & A \\
\hline 6 & A & $\mathrm{N}$ & $\mathrm{H}$ & $\mathrm{H}$ & A \\
\hline 7 & $\mathrm{~N}$ & $\mathrm{H}$ & $\mathrm{N}$ & $\mathrm{N}$ & $\mathrm{N}$ \\
\hline 8 & A & A & A & A & A \\
\hline 9 & $\mathrm{H}$ & A & $\mathrm{N}$ & A & $\mathrm{H}$ \\
\hline 10 & $\mathrm{~A}$ & A & $\mathrm{H}$ & A & A \\
\hline 11 & A & $\mathrm{N}$ & $\mathrm{N}$ & $\mathrm{N}$ & $\mathrm{N}$ \\
\hline 12 & A & A & $\mathrm{H}$ & A & A \\
\hline 13 & $N$ & $\mathrm{~N}$ & $\mathrm{~N}$ & $\mathrm{~N}$ & $\mathrm{~N}$ \\
\hline 14 & $\mathrm{~N}$ & $\mathrm{~N}$ & $\mathrm{~N}$ & $\mathrm{~N}$ & $N$ \\
\hline 15 & $\mathrm{H}$ & $\mathrm{N}$ & $\mathrm{N}$ & A & $\mathrm{N}$ \\
\hline 16 & A & $\mathrm{N}$ & $\mathrm{H}$ & $\mathrm{H}$ & A \\
\hline
\end{tabular}

Subjects 1-6 were from Mawson Station and subjects 7-16 from Davis Station. $N=$ normal, $\mathrm{H}=$ hypoergy, $\mathrm{A}=$ anergy. 
Figure1
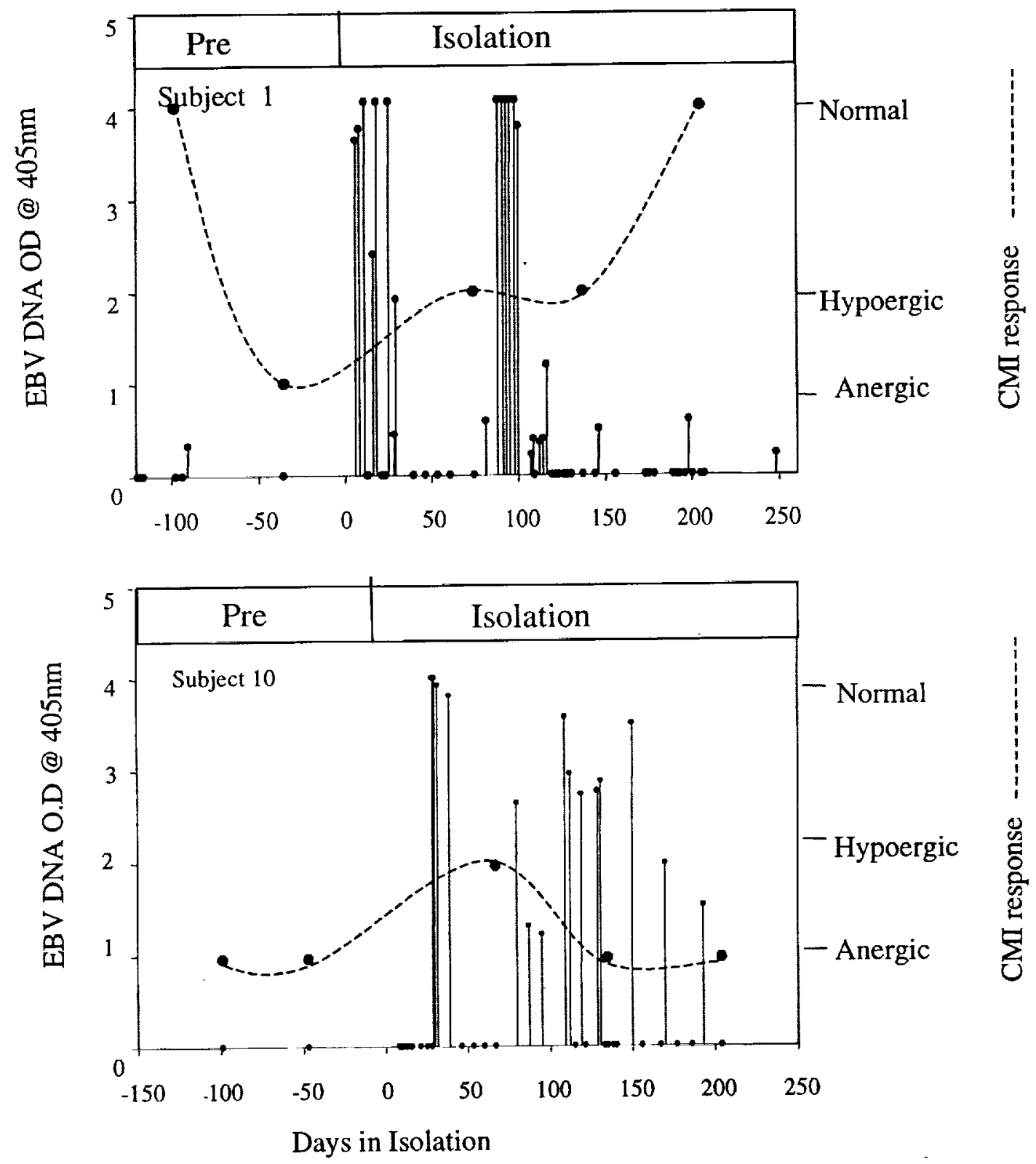
Figure 2
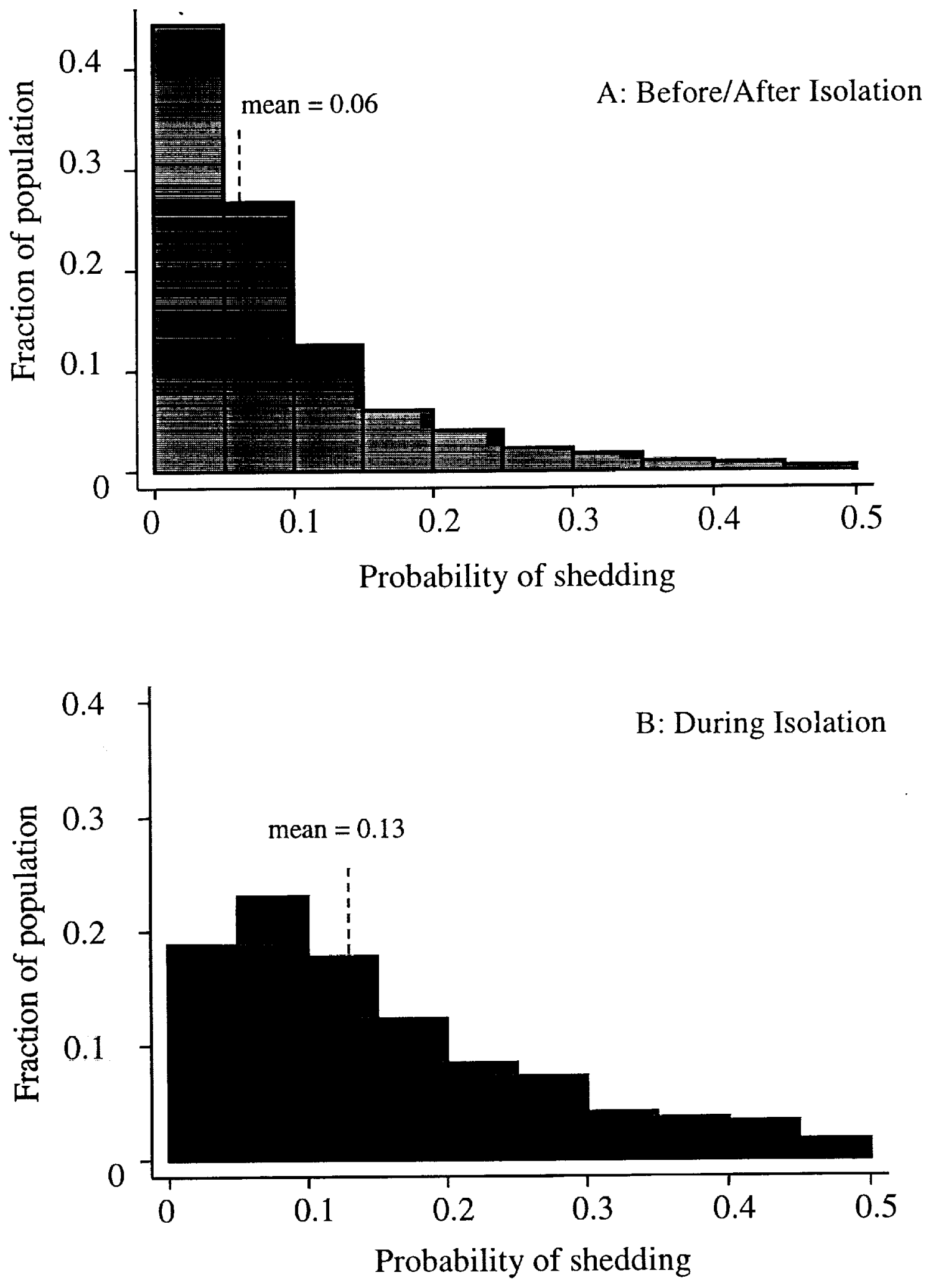
Figure 3

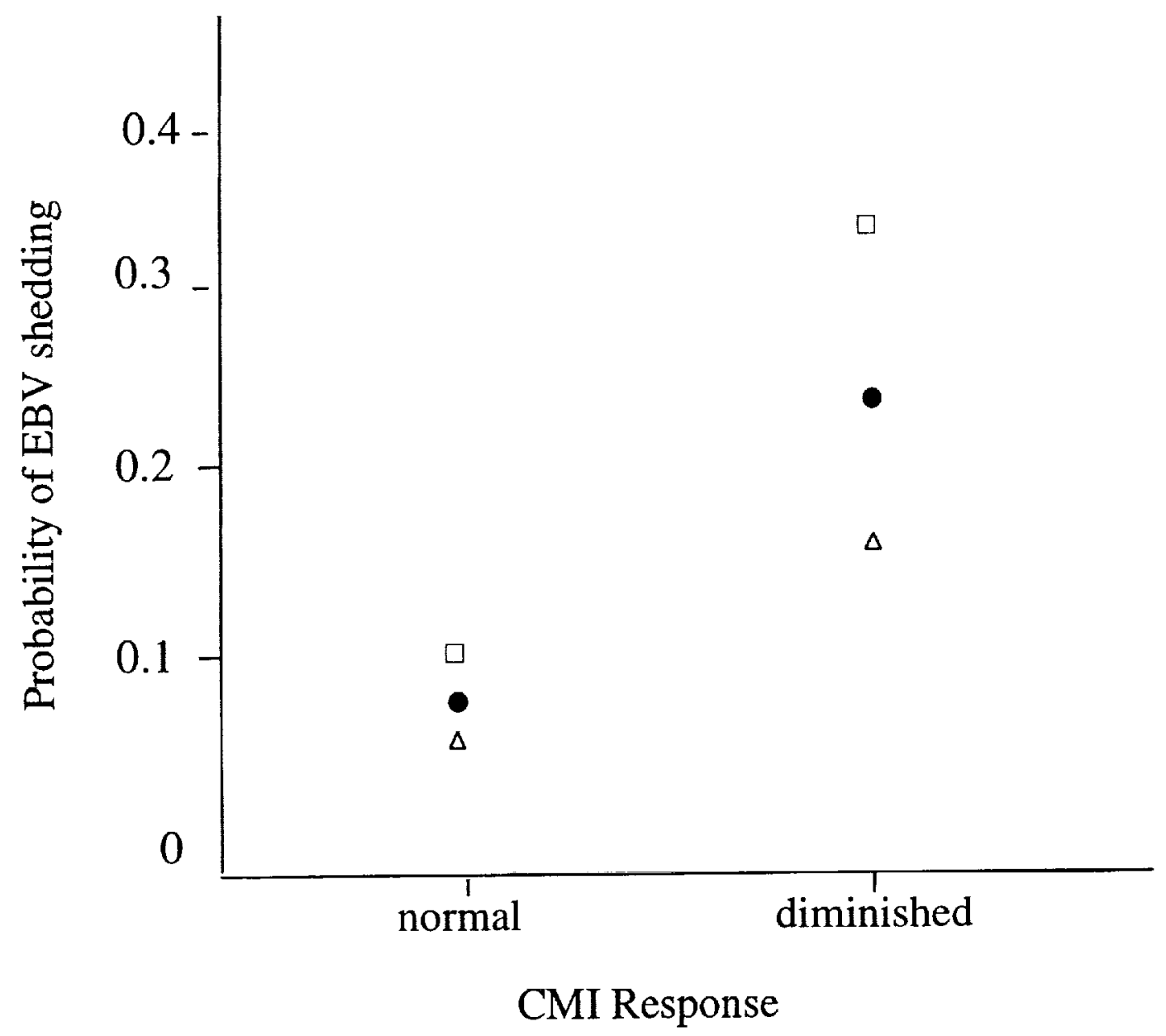

